\title{
Heart Failure: Prevalence, Symptoms, Treatments
}

\author{
Fatemeh Fatemifar* \\ Department of Mechanical Engineering, University of Texas at San Antonio, USA
}

Received: 畊 January 30, 2018; Published: 眥 February 08, 2018

*Corresponding author: Fatemeh Fatemifar, Department of Mechanical Engineering, University of Texas at San Antonio, USA

\section{Mini Review}

\section{Heart Failure Prevalence and Cost}

Heart failure (HF) is a growing epidemic that affects about six million people in the United States and more than 23 million worldwide [1,2].The prevalence of HF is greatest among people aged 65 years or older and has been increasing with the growth of this demographic population [3-6]. Around 50\% and $90 \%$ of patients with HF die within 5 and 10 years of diagnosis, respectively [1]. Total medical costs attributable to diagnosis, treatment, and prevention of HF in the developed countries are approximately $1 \%$ - $2 \%$ of the total health care expenditure [7-9]. In the United States, total costs for HF care are more than $\$ 39$ billion annually [2].

\section{Heart Failure Symptoms and Etiology}

HF patients suffer from structural or functional heart disease that impairs the ability of the ventricle to fill with or eject blood $[10,11]$. The symptoms of HF are shortness of breath/orthopnea/ dyspnea, fatigue, weakness, pulmonary congestion, edema, nocturnal cough, and evidence of a decrease in myocardial performance at rest $[12,13]$. Some of the etiologies that may lead to HF, are myocardial ischemia, hypertension, cardiomyopathies, valvular heart disease, obesity, pulmonary hypertension, abnormal myocyte calcium cycling, excessive or inadequate proliferation of the extracellular matrix, excessive neuro-humoral stimulation, accelerated apoptosis and genetic mutations congenital heart disease $[8,11,14]$.

\section{Heart Failure Types}

Classification of HF can be based on the left ventricular Ejection Fraction (EF): HF with Reduced EF (HFrEF) and HF with Preserved $\mathrm{EF}$ (HFpEF). In HFrEF patients, the heart is not able to pump enough blood into the circulation due to ventricular systolic dysfunction. The EF in these patients is less than or equal to $40 \%$ [15]. HFpEF is primarily caused by LV diastolic dysfunction (impaired relaxation during LV filling) due to the stiffening of the LV wall with $\mathrm{EF}>50 \%$ $[8,16,17]$. In addition to this classification schemes, HF can be classified based on ACCF/AHA stages of HF (Figure 1) [10].

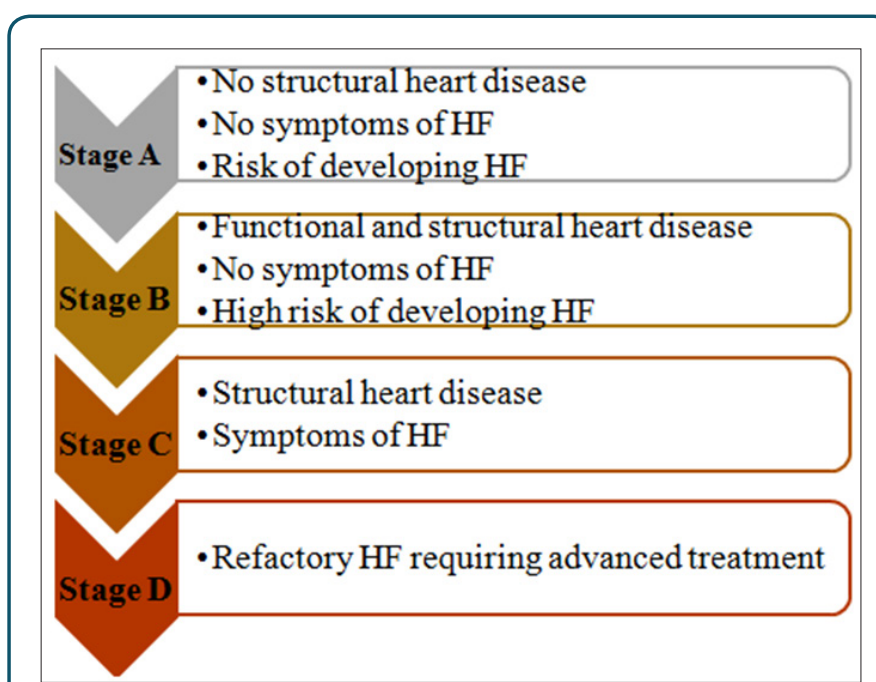

Figure 1: ACCF/AHA Stages of HF.

\section{Heart Failure Treatments}

The goal of HF treatment is to reduce the morbidity and mortality in these patients. For stage A and B, changing lifestyle (e.g. regular exercise and restriction of sodium intake), and using antihypertensive agent are recommended [8,10,15]. For stage B, C, and D, pharmacological therapy including diureticbased antihypertensive therapy, spironolactone, ACE inhibitors, angiotensin receptor blockers, Beta blockers, aldosterone antagonists, hydralazine and isosorbide dinitrates, digoxin, and anticoagulation are recommended. Advanced HF stage might need surgical treatment methods including coronary revascularization, mitral valve repair, ventricular reconstruction, and heart transplantation $[8,18]$.

\section{References}

1. Roger VL (2013) Epidemiology of Heart Failure. Circulation Research 113(6): 646-659.

2. Bui AL, Horwich TB, Fonarow GC (2011) Epidemiology and risk profile of heart failure. Nature reviews Cardiology 8(1): 30-41. 
3. Owan TE, Hodge DO, Herges RM, Jacobsen SJ, Roger VL, et al. (2006) Trends in Prevalence and Outcome of Heart Failure with Preserved Ejection Fraction. New England Journal of Medicine 355(3): 251-259.

4. Schulman KA, Mark DB, Califf RM (1998) Outcomes and costs within a disease management program for advanced congestive heart failure. Am Heart J 135(6 Pt 2 Su): S285-292.

5. Haldeman GA, Croft JB, Giles WH, Rashidee A (1999) Hospitalization of patients with heart failure: National Hospital Discharge Survey, 1985 to 1995. American Heart Journal 137(2): 352-360.

6. Mosterd A, Hoes AW (2007) Clinical epidemiology of heart failure. Heart 93(9): 1137-1146.

7. Stewart S, Jenkins A, Buchan S, McGuire A, Capewell S, et al. (2002) the current cost of heart failure to the National Health Service in the UK. European journal of heart failure 4(3): 361-371.

8. Pazos López P, Peteiro Vázquez J, Carcía Campos A, García Bueno L, de Torres JPA, et al. (2011)The causes, consequences, and treatment of left or right heart failure. Vascular Health and Risk Management 7: 237-254.

9. Dunlay SM, Shah ND, Shi Q, Morlan B, VanHouten H, et al. (2011) Lifetime costs of medical care after heart failure diagnosis. Circulation Cardiovascular quality and outcomes 4(1): 68-75.

10. Hunt SA, Abraham WT, Chin MH, Feldman AM, Francis GS, et al. (2009) 2009 Focused Update Incorporated Into the ACC/AHA 2005 Guidelines for the Diagnosis and Management of Heart Failure in Adults. 119(14): e391-e479.
11. Inamdar AA, Inamdar AC (2016) Heart Failure: Diagnosis, Management and Utilization. Journal of clinical medicine 5(7).

12. Yancy CW, Jessup M, Bozkurt B, Butler J, Casey DE, et al. (2013) 2013 ACCF/AHA Guideline for the Management of Heart Failure. A Report of the American College of Cardiology Foundation/American Heart Association Task Force on Practice Guidelines 128(16): e240-e327.

13. Watson RDS, Gibbs CR, Lip GYH (2000) Clinical features and complications. BMJ: British Medical Journal 320(7229): 236-239.

14. Dassanayaka S, Jones SP (2015) Recent Developments in Heart Failure. Circulation Research 117(7): e58.

15. Gedela M, Khan M, Jonsson O (2015) Heart Failure. South Dakota medicine: the journal of the South Dakota State Medical Association 68(9): 403-405.

16. Lekavich CL, Barksdale DJ, Neelon V, Wu JR (2015) Heart failure preserved ejection fraction (HFpEF): an integrated and strategic review. Heart Fail Rev 20(6): 643-653.

17. Fatemeh Fatemifar MF, Hai chao Han (2017) editor Characterization of biomechanical Properties of Human Trabeculae Carneae. Proceedings of the 2017 Summer Biomechanics, Bioengineering and Biotransport Conference.

18. Ramani GV, Uber PA, Mehra MR (2010) Chronic Heart Failure: Contemporary Diagnosis and Management. Mayo Clinic Proceedings 85(2): 180-195.

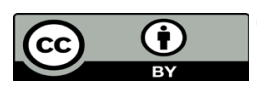

This work is licensed under Creative Commons Attribution 4.0 License

To Submit Your Article Click Here:

Submit Article

DOI: $10.32474 /$ OAJBEB.2018.01.000105

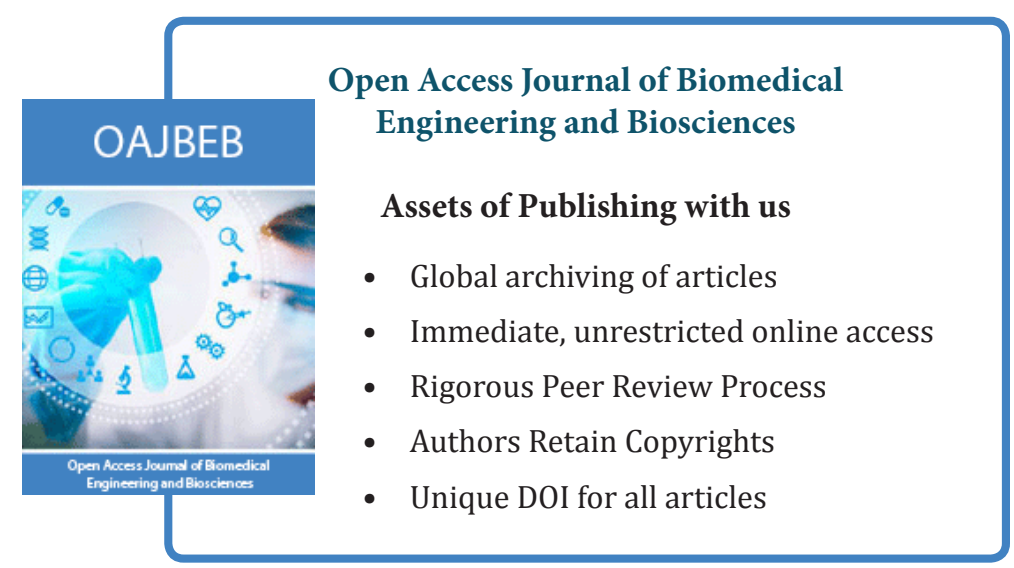

